\title{
Isolation and Characterization of Brenneria quercina, Causal Agent for Bark Canker and Drippy Nut of Quercus spp. in Spain
}

\author{
Elena G. Biosca, Raquel González, María José López-López, Santiago Soria, \\ Carmina Montón, Eduardo Pérez-Laorga, and María M. López
}

\begin{abstract}
First, second, third, and seventh authors: Instituto Valenciano de Investigaciones Agrarias, Moncada, 46113, Valencia, Spain; fourth author: Patrimonio Nacional, Palacio Real, 28071, Madrid, Spain; fifth author: Laboratori de Sanitat Vegetal, DARP, 08040, Barcelona, Spain; and sixth author: Servicio de Gestión Forestal, Consellería de Medio Ambiente, 46011, Valencia, Spain.
\end{abstract}

Accepted for publication 10 December 2002.

\begin{abstract}
Biosca, E. G., González, R., López-López, M. J., Soria, S., Montón, C., Pérez-Laorga, E., and López, M. M. 2003. Isolation and characterization of Brenneria quercina, causal agent for bark canker and drippy nut of Quercus spp. in Spain. Phytopathology 93:485-492.

The drippy nut disease of oak was first described in California in 1967 and, since then, the causal agent has not been reported in any other area. This study describes for the first time in Europe the isolation of Brenneria (Erwinia) quercina from bark canker in addition to drippy bud and drippy nut in Quercus ilex and Q. pyrenaica. The bark canker and drippy bud symptoms were not previously described as caused by this bacterium. No fungal pathogens were associated with any of the

pathogenic isolates from Spain as belonging to B. quercina, similar to the reference strain CFBP 1266. Fatty acid profiles of the Spanish isolates also were similar to the strain of B. quercina from California. Serological analysis by indirect immunofluorescence and enzyme-linked immunosorbent assay using polyclonal antisera against the reference strain of $B$. quercina and one Spanish oak isolate revealed some antigenic heterogeneity between isolates of different origins. Pathogenicity tests demonstrated that the Spanish isolates were able to reproduce internal symptoms of necrosis and acorn exudation in $Q$. ilex and $Q$. pyrenaica and suggest that $B$. quercina may be associated, among other causes, with the oak decline syndrome affecting Spanish oak forests.
\end{abstract} symptoms. Physiological and biochemical characterization identified the

In the last few decades, diverse symptomatology associated with oak decline syndrome has been reported in several European countries (4-6,21,26). The syndrome affects several Quercus species and, in Spain, it has been described on Q. ilex (holm oak) subsp. ilex and subsp. rotundifolia, $Q$. pyrenaica, $Q$. suber (cork oak), and $Q$. faginea. The affected trees suffer progressive loss of vigor, foliage reduction, and early leaf senescence. Rapid decline and death of the trees has been reported in some isolated cases. Among other symptoms, the affected oak trees often showed small longitudinal lesions of a few centimeters on the trunk bark which produce exudates, especially during the spring and autumn $(5,28)$. In some cases, bark cankers were very noticeable, reaching decimeters in length and affecting development. In other cases, very limited external symptoms were observed and it was only after removing the outer bark that extensive necrotic areas were revealed (28).

Abiotic and biotic factors are considered responsible for oak decline in Europe and the United States acting simultaneously or in succession $(1,16,32)$. Leininger (16) proposed that temperature and drought stress were related to this syndrome, suggesting that an increase of $1{ }^{\circ} \mathrm{C}$ in the maximum temperature during the growing season could have deleterious long-term effects on oak forests. In Spain, some studies have reached similar conclusions (8). In addition, certain fungi are known to be involved in the oak decline in Europe and California (i.e., Armillaria sp. [18], Phytophthora cinnamomi and Phytophthora ramorun [4,5,19,22,30], Diplodia

Corresponding author: María M. López; E-mail address: mlopez@ivia.es

Publication no. P-2003-0219-01R

(c) 2003 The American Phytopathological Society
Additional keywords: inoculation, phenotypic, serology. sp. [23], and Hypoxilon mediterraneum [31]). The affected oak species were $Q$. ilex and $Q$. suber in Spain and Lithocarpus densiflorus, $Q$. agrifolia, and $Q$. kelloggi in California $(4,22,30)$. None of these pathogens can be considered as the universal causal agent of the oak decline syndrome and the relative role of these organisms is still unclear in many cases.

With regard to bacterial pathogens, Scortichini et al. (27) described the association of several bacterial species with the decline of $Q$. cerris in central Italy, with P. agglomerans (Erwinia herbicola) being the species most frequently isolated from necrotic and healthy tissues. The role of Pantoea agglomerans in the development of the observed symptoms is still unknown because the isolated bacteria were not tested for pathogenicity. Barnard et al. (3) described the widespread occurrence of Xylella fastidiosa in Florida on populations of Q. laevis exhibiting decline or leaf scorch symptoms and the infrequent detection on asymptomatic trees. These authors used only a serological technique for detection and did not test the pathogenicity of $X$. fastidiosa isolates on oak; therefore, the causality of this bacterium in the observed symptoms remains to be confirmed.

Erwinia quercina, first described by Hildebrand and Schroth (12) as the etiological agent of drippy nut disease in $Q$. agrifolia and $Q$. wislizenni, recently was reclassified as Brenneria quercina by Hauben et al. (11). This bacterium was isolated from oozing and sticky acorns. The ooze was observed at the base of the nut and later on the acorn cup, after the nut had fallen (12). The disorders described by these authors were restricted to the nut and, although they recovered the bacterium from the surface of oak leaves, no symptoms on any other part of oak trees were reported. Little is known about this bacterial pathogen or the disease that it causes $(20,35)$. To our knowledge, the occurrence of drippy nut of 
oak has not been reported since its first description in 1967 by Hildebrand and Schroth (12).

During the past decade, oak species with decay symptoms and cankers have been found in several forests in central Spain. In all cases, bark cankers with exudates were observed. We describe here the first isolation of $B$. quercina from bark cankers on two Quercus species and the characterization of Spanish isolates compared to reference strains of other Brenneria spp. Furthermore, we describe new symptoms not yet associated with this bacterial pathogen.

\section{MATERIALS AND METHODS}

Symptoms and bacterial isolation. The affected trees were found in four forests located in central Spain. Necrotic outer and inner bark tissue samples from longitudinal cankers on the trunk bark and oozing acorns and buds were analyzed during spring and/or summer 1992, 1995, and 1996 (Table 1). Small sections in the border of necrotic and healthy tissues were aseptically excised, comminuted, and submerged in $10 \mathrm{mM}$ phosphate-buffered saline (PBS), pH 7.2, and directly streaked (or placed after dilutions) on King's B medium (14) plus cycloheximide $(250 \mathrm{mg} / \mathrm{ml})$. After incubation for 48 to $72 \mathrm{~h}$ at $25^{\circ} \mathrm{C}$, Brenneria-like colonies were selected and purified. Thirty-five isolates were obtained from trunk cankers, acorn, or bud exudations from $Q$. ilex and $Q$. pyrenaica trees.

Physiological and biochemical characterization. Bacterial strains were grown routinely in King's B medium (14) and incubated at $25^{\circ} \mathrm{C}$. They were presumptively identified to the species level by their Gram reaction, Kovac's oxidase, oxidative or fermentative metabolism, aesculin hydrolysis, urease and aminopeptidase activities, indol and levan production, pectate degradation, sucrose-reducing compounds, and hypersensitive reaction in tobacco leaves, as described by Schroth and Hildebrand (25). Two isolates from each origin were selected to confirm identification at the species level by using the multitube API 20E and API 20NE systems as recommended by the manufacturer (BioMérieux, Marcy-1'Etoile, France). The API 50CH system also was used but the inorganic medium of Ayers et al. (2) with $0.015 \%$ bromothymol blue was used as the basal medium to optimize the reactions. All the inoculated API strips were incubated at $25^{\circ} \mathrm{C}$ and read after 24 and $48 \mathrm{~h}$. One reference strain of B. quercina from Quercus sp. CFBP 1266, and reference strains of other Brenneria species (11) were used as controls (Table 1). All isolates were assayed at least twice.

Fatty acid profiles. Qualitative and quantitative cellular fatty acid analyses were conducted as described previously by Sasser (24). Fatty acid methyl esters (FAMEs) were extracted using hexane/methyl-tert butyl ether (MTBE) and analyzed with the Microbial Identification System (MIS, Hewlett-Packard model 5898) and the corresponding software (MIDI; Microbial ID, Inc. Newark, DE). Fatty acid profiles of selected isolates were com- pared with the reference strain CFBP 1266. Two chromatographic runs were made with the extract of each sample and the extractions were repeated at least twice. Individual FAMEs were quantified and identified using the peak-naming table component of the MIS software package. Quantities were expressed as percentages of the total named FAME peak area. The mean and standard deviation for each FAME were determined. FAMEs are referred to below as the parent fatty acids.

Serological characterization. The Spanish isolates and the reference strain of $B$. quercina CFBP 1266 were analyzed by indirect enzyme-linked immunosorbent assay (ELISA-I) and indirect immunofluorescence (IF-I), as described by Hampton et al. (10). Rabbit antisera were raised against whole cells and O-antigen of the reference strain of B. quercina CFBP 1266 and against whole cells of the Spanish isolate 1467a. The schedule of immunization was as follows: five intramuscular injection of $1 \mathrm{ml}$ $\left(10^{9} \mathrm{CFU} / \mathrm{ml}\right)$ weekly, except for one intravenous injection on day 21. Antisera were obtained 45 days after the first injection. Antisera titer was determined by ELISA-I and IF-I as described before (10). IF-I and ELISA-I were carried out in duplicate for each isolate and antiserum. PBS and Pseudomonas syringae pv. syringae 773-1 (from the Instituto Valenciano de Investigaciones Agrarias collection) were used as negative controls for IF-I and ELISA-I, respectively.

Pathogenicity tests. One isolate from each origin was selected for pathogenicity assays on acorn, using five acorns per bacterial isolate. The reference strain of B. quercina CFBP 1266 and PBS were used as positive and negative controls, respectively. Mature acorns were rinsed, disinfected for 5 min with a solution of $0.5 \%$ sodium hypochloride and 3\% ethanol (wt/vol), and rinsed again with sterile distilled water prior to inoculation, as previously described by Hildebrand and Schroth (12). Several attempts were made to reproduce the symptoms caused by $B$. quercina. First, acorns detached from holm oak were punctured with a needle, a drop of a bacterial suspension in PBS $\left(10^{9} \mathrm{CFU} / \mathrm{ml}\right)$ was placed in the wound, and the inoculated nut was incubated in a sterile moist chamber at $29^{\circ} \mathrm{C}$, as described by Hildebrand and Schroth (12). In a second method, disinfected acorns attached to small branches were immersed in a bacterial suspension $\left(10^{9} \mathrm{CFU} / \mathrm{ml}\right)$, placed in sterile $1 \%$ agar $(\mathrm{wt} / \mathrm{vol})$ in closed $500-\mathrm{ml}$ bottles, and incubated at $25^{\circ} \mathrm{C}$. Symptoms appearance was monitored for 2 weeks. Bacteria were reisolated on King's B medium (14). The experiments were repeated at least once.

Trunk inoculations were conducted on $Q$. ilex and $Q$. pyrenaica trees grown in pots or identified in the forest. The group of potted trees consisted of 288, 3- to 5-year-old, $Q$. ilex and $Q$. pyrenaica specimens. The 72 oak trees tested in the forest were at least 20 years old. $Q$. ilex and $Q$. pyrenaica trees were inoculated in the summer with one representative bacterial isolate from each host species, 1442-2b from holm oak and 1467 a from $Q$. pyrenaica. Groups of 24 young plants or 6 mature trees were inoculated per strain and the experiments were performed in duplicate. The

TABLE 1. Origin of analyzed Quercus samples and reference strains of Brenneria spp. used

\begin{tabular}{|c|c|c|c|c|c|}
\hline Bacterial sample, strain ${ }^{a}$ & Host & Origin & Isolation date & Tissue source & Symptoms \\
\hline 1251 (6 isolates) & Q. ilex & El Pardo (Madrid) & 1992 & Trunk bark & Exudative canker \\
\hline 1442 (8 isolates) & Q. ilex & El Pardo (Madrid) & 1995 & Trunk bark & Exudative canker \\
\hline 1467 (6 isolates) & Q. pyrenaica & El Escorial (Madrid) & 1995 & Trunk bark & Exudative canker \\
\hline 1625 (10 isolates $)$ & Q. pyrenaica & Soto del Real (Madrid) & 1996 & Buds & Drippy buds \\
\hline B. quercina CFBP 1266 & Quercus sp. & California, USA & 1967 & Acorns & $\ldots$ \\
\hline B. alni CFBP $3923^{\mathrm{T}}$ & Alnus cordata & Italy & 1996 & Trunk bark & $\ldots$ \\
\hline B. nigrifluens NCPPB $564^{\mathrm{T}}$ & Juglans regia & California, USA & 1957 & Trunk bark & $\ldots$ \\
\hline B. salicis CFBP $802^{\mathrm{T}}$ & Salix alba caerulae & United Kingdom & 1939 & Xylem & $\ldots$ \\
\hline
\end{tabular}

${ }^{a}$ CFBP $=$ Collection Française de Bactéries Phytopathogènes, INRA, France; T = type strain; NCPPB = National Collection of Plant Pathogenic Bacteria, York, England. 
Californian strain CFBP 1266 and PBS were used as positive and negative controls, respectively. The bark surface was disinfected with $95 \%$ ethanol prior to making a transverse cut with a disinfected scalpel into the bark. The bacterial suspension in PBS $\left(10^{9} \mathrm{CFU} / \mathrm{ml}\right)$ was injected into the wound ( 25 to $50 \mu \mathrm{l}$ and $400 \mu \mathrm{l}$ for young and old trees, respectively), and the wounds were sealed with plastic film. Plants in pots were maintained in the open air. The appearance of external and internal symptoms was recorded before and after removing the bark and measuring the length of the affected tissue 3 and 28 months after inoculation. Bacteria were recovered from symptomatic plants on King's B medium (14).

Statistical analysis. Statistical analysis of pathogenicity experiments data was performed using the statistical analysis package SPSS/PC (version 9.0 for Windows; SPSS Inc., Chicago). The Fisher's Exact Test for categorical data was used to study possible differences in symptoms occurrence between the following groups: (i) trees inoculated with strains from $Q$. ilex or $Q$. pyrenaica, (ii) young or mature oak trees, (iii) $Q$. ilex or $Q$. pyrenaica trees, and (iv) trees with symptoms observed 3 or 28 months after inoculation in each of above-mentioned groups. Statistical significance was accepted for all values of $P$ lower than 0.05 .

\section{RESULTS}

Symptomatology. Unlike the drippy nut disease described in California, the first symptoms observed in Spain were bark cankers, but the drippy nut was observed in subsequent surveys. A frequent symptom was the presence of irregular longitudinal cankers of a few centimeters in size on the trunk (Fig. 1) and branches (Fig. 2), reaching in some cases to $20 \mathrm{~cm}$. These can-

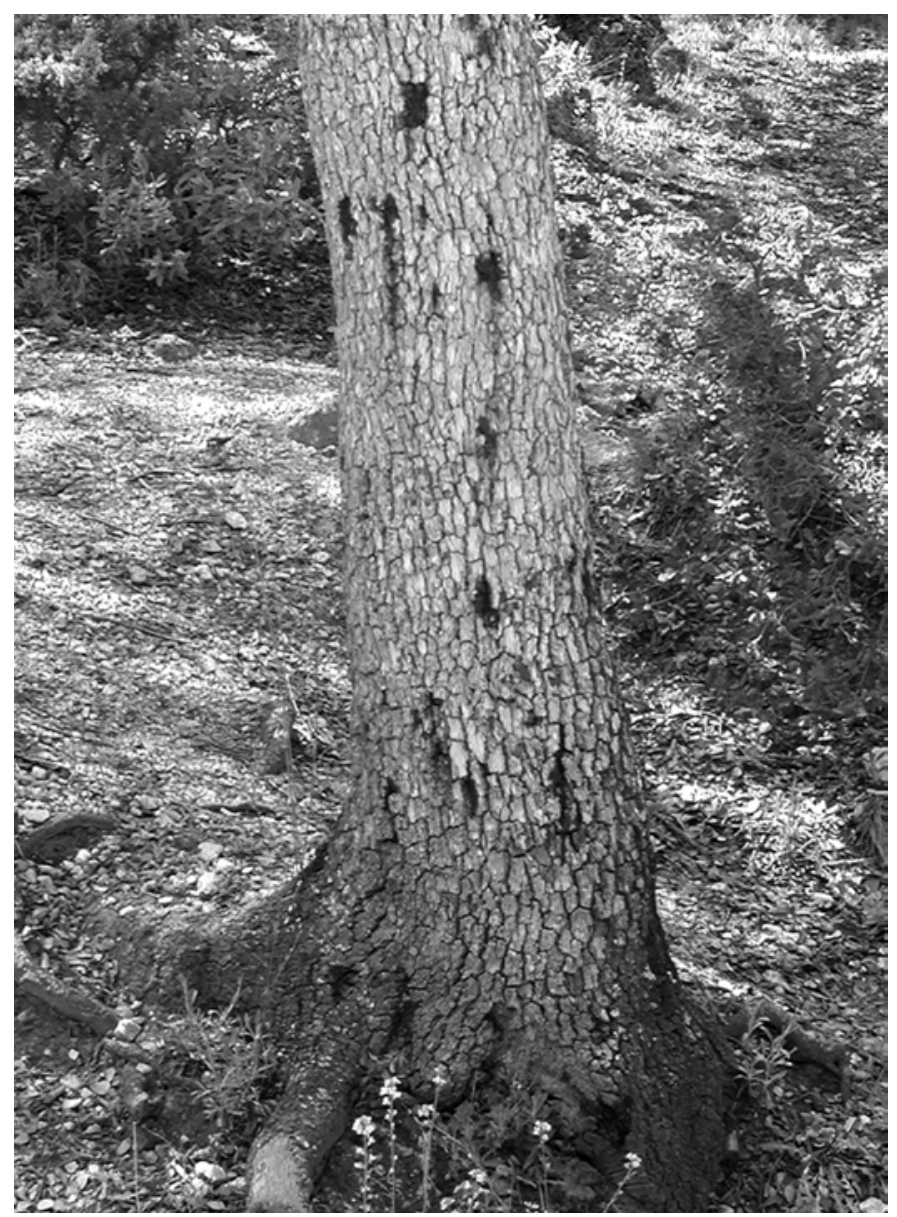

Fig. 1. Trunk cankers with dark exudates staining the bark of a Quercus ilex tree seriously affected by Brenneria quercina. kers, variable in depth, and showing necrosis of the affected tissues and copious exudation, usually appeared on the bark surface of the lower trunk. Necrotic lesions extended to inner bark tissues, reaching the pith in the smaller branches. In some cases, from small cankers of only few centimeters, we observed extensive internal lesions. The exudates, observed mainly during autumn and spring, were variously colored from white and frothy to a reddish or brownish color. They gradually became darker as they dried, and the surrounding bark turned reddish and finally dark brown or blackish. Oak trees seriously affected by bark cankers were usually mature (more than 20 years old), showing a progressive loss of vigor, foliage reduction, and early leaf senescence.

Exudates frequently were observed in growing acorns. This copious, sticky, honey-like sap appeared under the acorn cup (Fig. 3) and was responsible for severe fruit drop. Consequently, infected trees produced fewer acorns, most of which rotted and fell from the acorn cup. Exudations from leaf buds also were observed in some affected $Q$. pyrenaica trees, a symptom not previously described as being caused by $B$. quercina.

Bacteriological analysis. Bacterial colonies with morphological characters similar to B. quercina were isolated on King's B medium from trunk cankers and from acorn and bud exudations from $Q$. ilex and $Q$. pyrenaica. Almost pure cultures frequently were obtained. Colonies were cream in color, slightly convex, and circular, with entire margins and a shiny transparent texture, and did not produce pigments on this medium. Isolates initially were identified as belonging to the species $B$. quercina according to Hildebrand and Schroth (12) and Hauben et al. (11), because they were gram negative, oxidase negative, facultatively anaerobic, aesculin positive, urease negative, and produced sucrose-reducing

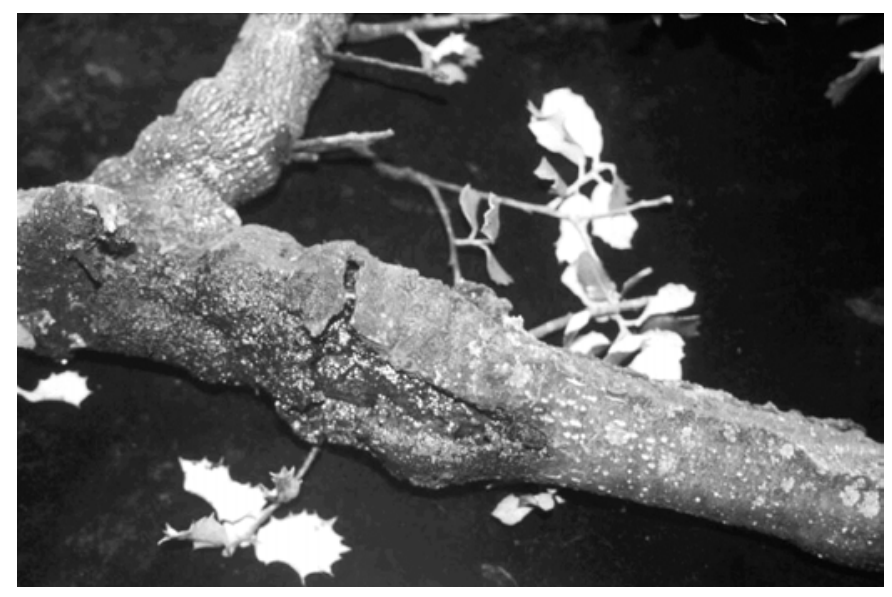

Fig. 2. Bark canker on branch of a Quercus ilex tree exhibiting symptoms of Brenneria quercina, with necrotic lesions and dark exudates.

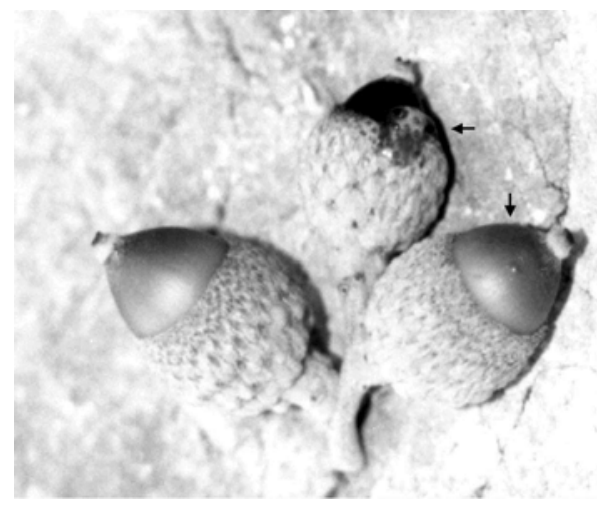

Fig. 3. Copious oozing of bacteria and sap from growing acorns of a Quercus ilex tree (the arrows indicate two acorns with ooze). 
compounds, aminopeptidase, and mucoid growth in levan medium. They grew in King's B broth (14) at $37^{\circ} \mathrm{C}$, were negative for nitrate reduction and pectate degradation, and did not induce a hypersensitive response in tobacco leaves.

Physiological and biochemical characterization. Ten selected isolates from five origins were analyzed further by API 20E, API 20NE, and API 50CH tests and compared with strain CFBP 1266 of $B$. quercina and the reference strains of other Brenneria species. The API 20E and API 20 NE systems revealed that all Spanish isolates had similar biochemical characteristics and resembled the reference strain CFBP 1266 (Table 2). In the API 20E strip, some false positive results were observed in acid production from inositol, rhamnose, melibiose, and arabinose after $48 \mathrm{~h}$ by all assayed isolates when compared with the results from the API $50 \mathrm{CH}$ and those from the literature (11-13). Thus, only the 24-h results for acid production were recorded (Table 2). The Spanish oak isolates differed in several tests of the API 20E and API 20NE strips from the reference strains of $B$. alni, B. nigrifluens, $B$. rubrifaciens, B. paradisiaca, and B. salicis (Table 2).

The modified API 50CH system also revealed homogeneous profiles for Spanish oak isolates, all of them being able to produce acid within $48 \mathrm{~h}$ from ribose, glucose, D-fructose, D-mannose, mannitol, $N$-acetylglucosamine, arbutine, esculine, salicin, sucrose, and gluconate, but not from erythritol, D-arabinose, Larabinose, D-xylose, L-xylose, adonitol, L-sorbose, rhamnose, dulcitol, inositol, sorbitol, $\alpha$-methyl-mannoside, cellobiose, maltose, lactose, melibiose, inulin, $\alpha$-D-melezitose, D-raffinose, starch, glycogen, xylitol, $\beta$-gentibiose, D-lyxose, D-tagatose, D-fucose, L-fucose, D-arabitol, L-arabitol, 2-keto-gluconate, and 5-keto-gluconate. The reference strain CFBP 1266 also acidified glycerol and galactose, sugars utilized by 5 and 8, respectively, out of 10 Spanish strains. These results also confirm the identification of Spanish oak isolates as B. quercina, according to Hildebrand and Schroth (12) and Hauben et al. (11).

TABLE 2. Physiological and biochemical characteristics of the Spanish oak isolates and reference strains of Brenneria quercina and other Brenneria species using the API 20E and API 20NE systems ${ }^{\mathrm{a}}$

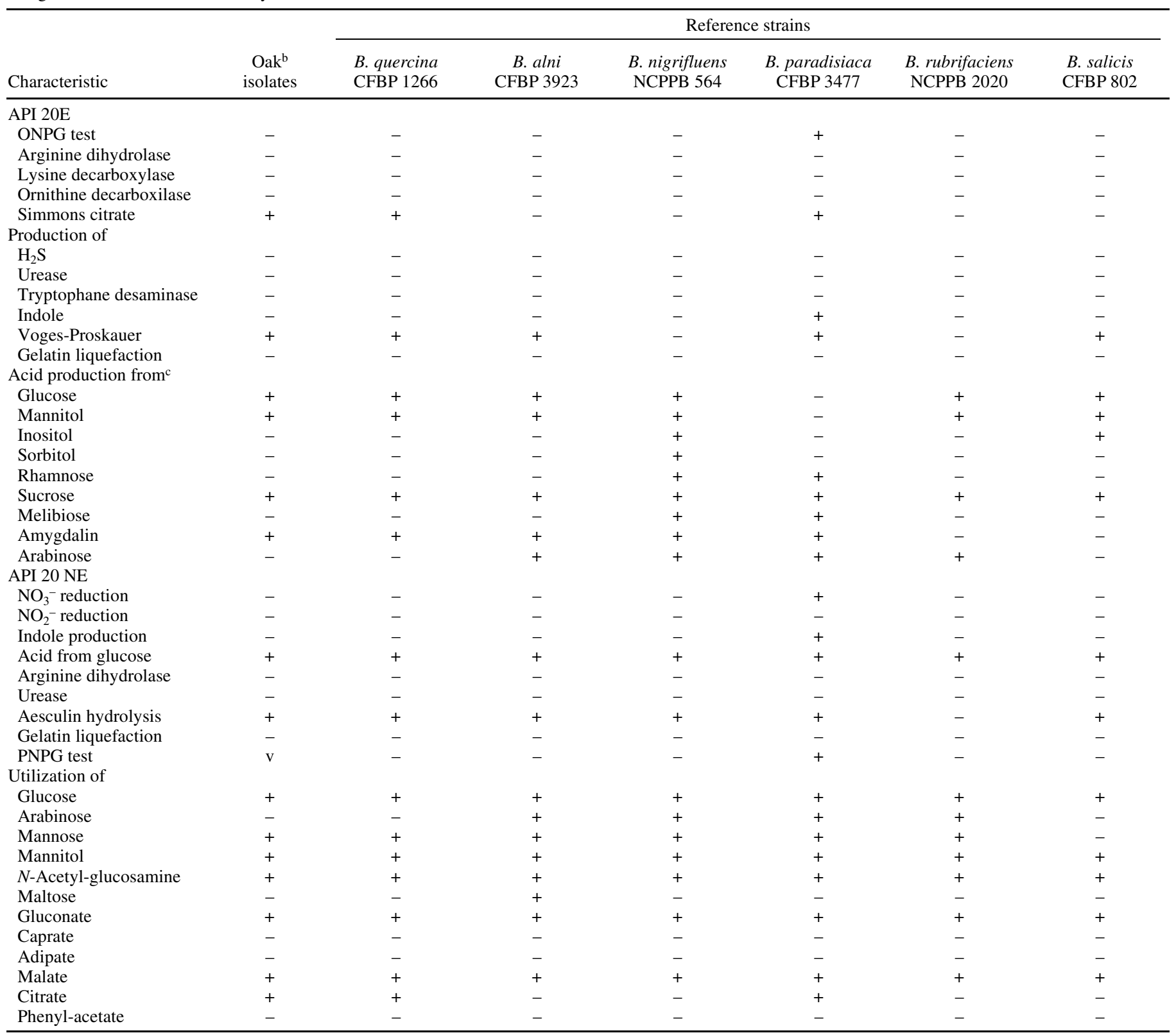

${ }^{a}$ CFBP $=$ Collection Française de Bactéries Phytopathogènes, INRA, France and NCPPB = National Collection of Plant Pathogenic Bacteria, York, England. Strain possesses character $(+)$, does not possess character (-), or variable (v).

b Ten Spanish oak isolates.

${ }^{c}$ After $24 \mathrm{~h}$ of incubation at $25^{\circ} \mathrm{C}$. 
Fatty acid profiles. The mean percentages of peak areas for all the major FAMEs are shown in Table 3. They include the saturated fatty acids 14:0 and 16:0, the monosaturated fatty acids 16:1 w7c and 18:1 w7c, the cyclopropane fatty acid 17:0 cyclo, and the hydroxy fatty acids $14: 03 \mathrm{OH}$. The minor fatty acids were 12:0, 15:0, 18:0, 19:0 cyclo, 15:0 iso $3 \mathrm{OH}$, and an as-yet-unknown fatty acid with an equivalent chain length of 14.503. Minor FAMEs that were present at low values or only in one or two strains were omitted. The total peak area of the gas chromatography profiles was within the range of values that avoided the loss of peaks with less than $1 \%$ of the total named peak area. This was assessed in a previous assay using lipids from different weights of fresh cells. The reproducibility of the profiles was good and standard deviations were low (Table 3).

The Spanish strains and the reference strain were not identified as Erwinia (Brenneria) quercina as the first choice of the MIS; they were identified as Edwarsiella hoshinae, Proteus vulgaris, or Pasteurella haemolytica. However, six of these strains were identified as Erwinia quercina as second or third or fourth choice with similarity indices between 0.58 and 0.71 .

Serological analysis. The working dilutions of the three antisera in IF-I and ELISA-I were 1:1,000 and 1:25,000, respectively, for AS-1266-WC; 1:400 and 1:5,000, respectively, for AS-1266-O (prepared with the Californian strain); and 1:300 and 1:25,000, respectively, for AS-1467a-WC (prepared with the Spanish strain). The reactions of the Spanish oak isolates and the reference strain
1266 in IF-I and ELISA-I with the three antisera are shown in Table 4. Antisera obtained with strain CFBP 1266 (using whole cells and somatic antigen) and isolate 1467a (using whole cells) showed a high reactivity with their homologous strains used for rabbit immunization as well as with the heterologous ones. AS 1266-WC, AS 1266-O, and AS 1467a-WC reacted with 8, 8, and 7 out of 10 Spanish isolates of B. quercina, respectively, by IF-I and with 5,8 , and 10 out of 10 isolates, respectively, by ELISA-I. None of three antisera reacted with all isolates by IF-I at the dilutions tested (Table 4). By ELISA-I, only the antiserum for the Spanish isolate 1467 a reacted with all Spanish isolates of $B$. quercina. Some differences were observed by IF-I between antisera obtained from whole cells and from somatic antigen of strain CFBP 1266, suggesting differences in surface antigens. Results obtained with the three antisera and the two serological techniques showed serological heterogeneity among Spanish oak isolates from different origins.

Pathogenicity tests. Oozing was not observed 2 weeks after inoculation of needle wounds on holm oak nuts. However, ooze was observed within a week on acorns inoculated by immersion in suspensions of the Spanish isolates and the Californian strain of $B$. quercina. Bacterial isolates having the same characteristics as those inoculated were recovered from nut oozing.

The results of inoculating pot-grown or field-grown oaks with the bacterial isolates are given in Table 5. Three months after inoculation, external cankers like those observed under natural

TABLE 3. Fatty acid composition (percentage of peak areas) of Brenneria quercina Spanish isolates from Quercus ilex and $Q$. pyrenaica $^{\text {a }}$

\begin{tabular}{|c|c|c|c|c|c|c|}
\hline Fatty acid class & CFBP 1266 & $1251(n=2)$ & $1442(n=2)$ & $1467(n=2)$ & $1618(n=2)$ & $1625(n=2)$ \\
\hline \multicolumn{7}{|l|}{ Saturated fatty acids } \\
\hline $12: 0$ & $0.57(0.0)$ & $0.59(0.04)$ & $0.51(0.03)$ & $0.57(0.02)$ & $0.49(0.03)$ & $0.56(0.07)$ \\
\hline $14: 0$ & $11.20(0.13)$ & $11.19(0.33)$ & $10.22(0.15)$ & $10.18(0.20)$ & $10.25(0.18)$ & $10.07(0.05)$ \\
\hline $15: 0$ & $0.46(0.07)$ & $0.13(0.05)$ & $0.86(0.40)$ & $0.50(0.20)$ & $0.80(0.09)$ & $0.72(0.20)$ \\
\hline $16: 0$ & $33.92(0.37)$ & $33.42(0.61)$ & $33.31(0.36)$ & $32.50(1.02)$ & $33.39(0.62)$ & $32.78(0.14)$ \\
\hline $18: 0$ & $0.30(0.03)$ & $0.34(0.40)$ & $0.49(0.11)$ & $0.39(0.07)$ & $0.38(0.04)$ & $0.35(0.02)$ \\
\hline \multicolumn{7}{|l|}{ Unsaturated fatty acids } \\
\hline $16: 1 \mathrm{w} 7 \mathrm{c}$ & $23.93(1.83)$ & $25.48(1.08)$ & $26.48(1.04)$ & $26.86(1.08)$ & $27.68(1.18)$ & $27.97(1.13)$ \\
\hline $18: 1 \mathrm{w} 7 \mathrm{c}$ & $8.15(0.91)$ & $11.77(1.12)$ & $11.70(0.74)$ & $12.04(0.82)$ & $11.91(0.90)$ & $12.16(0.66)$ \\
\hline \multicolumn{7}{|c|}{ Cyclopropane fatty acids } \\
\hline $17: 0$ & $8.92(1.17)$ & $6.34(1.28)$ & $4.58(0.79)$ & $4.52(0.67)$ & $4.39(0.52)$ & $3.81(0.47)$ \\
\hline $19: 0$ & $1.40(0.31)$ & $1.17(0.24)$ & $0.73(0.16)$ & $0.69(0.20)$ & $0.77(0.17)$ & $0.63(0.04)$ \\
\hline \multicolumn{7}{|l|}{ Hydroxy fatty acids } \\
\hline $14: 03 \mathrm{OH}$ & $9.41(0.2)$ & $8.20(0.24)$ & $9.03(0.08)$ & $9.05(0.27)$ & $9.28(0.16)$ & $9.29(0.19)$ \\
\hline $15: 0$ iso $3 \mathrm{OH}$ & $0.42(0.13)$ & $0.82(0.18)$ & $0.45(0.19)$ & $0.58(0.08)$ & $0.06(0.06)$ & $0.11(0.06)$ \\
\hline Unknown $14.503^{\mathrm{b}}$ & $0.80(0.0)$ & $0.95(0.04)$ & $0.81(0.06)$ & $0.80(0.03)$ & $0.88(0.1)$ & $0.35(0.18)$ \\
\hline
\end{tabular}

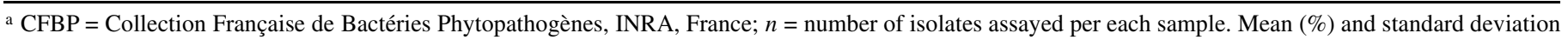
of two extractions of two strains per each sample.

b Equivalent chain length relative to the lengths of known fatty acids.

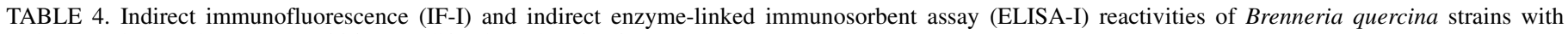
antisera against strains CFBP 1266 from California and 1467a from Spain ${ }^{\mathrm{a}}$

\begin{tabular}{|c|c|c|c|c|c|c|}
\hline \multirow[b]{3}{*}{ Strain } & \multicolumn{3}{|c|}{ IF-I reactivity with antiserum ${ }^{b}$} & \multicolumn{3}{|c|}{ ELISA-I reactivity with antiserum ${ }^{c}$} \\
\hline & \multicolumn{2}{|c|}{ AS 1266} & \multirow{2}{*}{$\frac{\text { AS 1467-a }}{\text { WC }}$} & \multicolumn{2}{|c|}{ AS 1266} & \multirow{2}{*}{$\frac{\text { AS 1467-a }}{\text { WC }}$} \\
\hline & WC & $\mathrm{O}$ & & WC & $\mathrm{O}$ & \\
\hline CFBP 1266 & +++ & +++ & ++ & +++ & +++ & +++ \\
\hline $1251-3$ & ++ & + & + & ++ & ++ & +++ \\
\hline $1251-5$ & ++ & + & ++ & +++ & +++ & +++ \\
\hline $1442-2$ & + & + & + & - & - & ++ \\
\hline $1442-8$ & + & - & + & + & +++ & +++ \\
\hline $1467-\mathrm{a}$ & ++ & - & ++ & +++ & +++ & +++ \\
\hline 1467-h & ++ & + & + & ++ & +++ & +++ \\
\hline $1618-a$ & + & + & - & - & + & ++ \\
\hline 1618-e & - & + & + & - & - & + \\
\hline $1625-1$ & + & + & - & - & ++ & ++ \\
\hline $1625-2$ & - & + & - & - & + & + \\
\hline
\end{tabular}

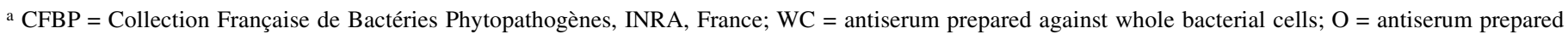
against $\mathrm{O}$ antigen.

$\mathrm{b}+++=$ Similar reaction to the homologous strain; $++=$ weaker reaction than the homologous; $+=$ weak reaction; $-=$ negative reaction .

$c^{c}++=$ Optical density at $405 \mathrm{~nm}\left(\mathrm{OD}_{405 \mathrm{~nm}}\right) \geq 2 ;++=2<\mathrm{OD}_{405 \mathrm{~nm}} \leq 1 ;+=1<\mathrm{OD}_{405 \mathrm{~nm}}>0.5 ;-=\mathrm{OD}_{405 \mathrm{~nm}} \leq 0.5$, negative control $=\mathrm{OD}_{405 \mathrm{~nm}} \leq 0.25$. 
conditions were not visible, but small areas of necrotic tissue appeared in the bark above and below the inoculation points. When the bark was removed, brown necrotic streaks from 5 to $35 \mathrm{~mm}$ in length in young plants and from 20 to $150 \mathrm{~mm}$ in length in mature trees were observed around the inoculation sites in $Q$. ilex and $Q$. pyrenaica. Bacteria that resembled those used in inoculations were recovered from the lesions (Table 5). Thus, the Spanish isolates and the reference strain CFBP 1266 from drippy nut were able to produce internal symptoms in holm oak and $Q$. pyrenaica, irrespective of their origin. No differences were observed between isolates coming from $Q$. ilex, $Q$. pyrenaica, or California in their ability to produce lesions in any of the species assayed. Typical external cankers were not observed in most of the oak trees after 3 months; therefore, half of the inoculated trees were analyzed after 28 months. In general, trees did not show a progression of external symptoms, except for a few potted trees in which cracking of the trunk bark and development of external cankers with exudates occurred. B. quercina was reisolated from these cankers. No differences were found in the length of the inner lesions on oak trees growing in the field analyzed after 3 or 28 months, which ranged from 25 to $150 \mathrm{~mm}$ for $Q$. ilex and from 20 to $120 \mathrm{~mm}$ for $Q$. pyrenaica, irrespective of the origin of the inoculated strain. However, the length of the inner affected tissues on young pot-grown oaks after 28 months progressed up to $145 \mathrm{~mm}$. Statistical analysis of data showed significant differences $(P<0.05)$ in symptom occurrence in the 3 - to 5-year-old holm oak trees analyzed 3 or 28 months after inoculation, regardless the strain assayed (Table 5). Thus, for pathogenicity experiments using young holm oaks, trees should be analyzed after more than 3 months and, when possible, after 2 years. The majority of inoculated trees showed similar internal lesions and reisolated strains were identified as B. quercina (Table 5).

\section{DISCUSSION}

The bacterium causing exudative bark cankers in Spanish oak forests originally was isolated in 1992 from holm oaks (Q. ilex). The symptoms consisted of bark cankers with dark and sticky exudates, which had been observed over several years. Similar lesions on the trunk of walnut trees and alders are caused by species belonging to the genus Brenneria (Erwinia), such as $B$. nigrifluens $(11,33), B$. rubrifaciens $(11,34)$, and $B$. alni, respectively $(11,29)$. They were described as responsible for bark canker and phloem canker of Persian walnut trees and bark canker of alder trees. The main symptom of such diseases is a dark, exudative canker on the trunk bark, which is limited to the outer bark for $B$. nigrifluens (33), to the inner bark and cambium for $B$. rubrifaciens (34), and to the bark for B. alni (29). B. nigrifluens and B. rubrifaciens recently have been identified, for the first time in Europe, as causing trunk cankers on Spanish trees $(9,17)$. In diseased oak trees, the symptoms looked very similar, with longitudinal cracks extending through the affected areas and with ooze sometimes escaping from the canker and dripping over the bark surface. We have maintained the name canker for the exudative lesions observed on oaks trees, although they are not typical bacterial cankers. From these oaks, we isolated a bacterium with morphological and physiological characteristics similar to those reported for $B$. quercina (11-13), which differs from $B$. nigrifluens, B. rubrifaciens, and B. alni in several tests. To our knowledge, $B$. quercina had never been identified outside California nor associated with bark cankers.

Samples of exudative cankers from different origins were analyzed and similar bacteria were isolated in 1995 from $Q$. ilex and $Q$. pyrenaica, demonstrating a consistent association of $B$. quercina with cankers. Some attempts were made to isolate fungal pathogens from these samples, looking for those previously associated with the oak decline in Spain and other countries (1821). No fungi were associated with bark cankers, drippy nut, or drippy bud and no Phytophthora sp. was isolated from the roots or the surrounding soil of the affected trees (28).

B. quercina was described by Hildebrand and Schroth as the causal agent of the drippy nut disease of California live oaks (12). The sole symptom described by these authors was a copious oozing of plant sap from the acorns and some rotting of the nut. Surveys from 1996 in forests close to Madrid demonstrated that both symptoms were very widespread in all the surveyed areas. An initial damage evaluation revealed that approximately 30 to $40 \%$ of the acorns were affected (28). Acorns are a valuable food source for wild life and are harvested for feeding the Iberian pig; therefore, the economic losses caused by this disease are relevant.

When comparing the Spanish isolates from bark cankers, as well as acorn and bud exudations, with the Californian strain CFBF 1266 by means of the API 20E and API 20 NE systems, we observed similar results in the utilization of sugars and other organic compounds. However, the Spanish isolates were clearly different from the other reference strains of Brenneria spp. assayed (Table 2). With API 50CH strips, we also observed homogeneous profiles for the Spanish isolates and the reference strain of B. quercina. However, differences in acid production from some sugars were observed between the API 20E (after $48 \mathrm{~h}$ ) and the API 50CH results. They could be due to the different amount of bromothymol blue used in the API 20E gallery or to the modified basal medium. To increase the repeatability of the results with the API $50 \mathrm{CH}$, we changed the commercial basal medium to Ayers medium and increased the amount of bromothymol blue to $0.015 \%$ (wt/vol).

TABLE 5. Pathogenicity of Brenneria quercina strains for Quercus ilex and Q. pyrenaica

\begin{tabular}{|c|c|c|c|c|c|c|c|c|c|c|c|c|}
\hline \multirow[b]{5}{*}{ Strain } & \multicolumn{12}{|c|}{ Trees with symptoms/analyzed trees ${ }^{\mathrm{a}}$} \\
\hline & \multicolumn{6}{|c|}{3 years old } & \multicolumn{6}{|c|}{$>20$ years old } \\
\hline & \multicolumn{3}{|c|}{ Q. ilex } & \multicolumn{3}{|c|}{ Q. pyrenaica } & \multicolumn{3}{|c|}{ Q. ilex } & \multicolumn{3}{|c|}{ Q. pyrenaica } \\
\hline & \multicolumn{2}{|c|}{ Months } & \multirow[b]{2}{*}{ Reisol } & \multicolumn{2}{|c|}{ Months } & \multirow[b]{2}{*}{ Reisol } & \multicolumn{2}{|c|}{ Months } & \multirow[b]{2}{*}{ Reisol } & \multicolumn{2}{|c|}{ Months } & \multirow[b]{2}{*}{ Reisol } \\
\hline & 3 & 28 & & 3 & 28 & & 3 & 28 & & 3 & 28 & \\
\hline CFBP1266 & $3 / 9$ & $4 / 4$ & ND & $4 / 8$ & $4 / 4$ & + & $4 / 4$ & NT & + & $2 / 3$ & $\mathrm{NT}$ & + \\
\hline CFBP1266 & $2 / 9$ & $3 / 4$ & ND & $6 / 8$ & $4 / 4$ & + & $3 / 4$ & NT & + & $2 / 4$ & NT & + \\
\hline $1442-2 b$ & $6 / 13^{b}$ & $9 / 9^{b}$ & + & $10 / 13$ & $6 / 11$ & + & $2 / 3$ & $3 / 3$ & + & $2 / 3$ & $3 / 3$ & + \\
\hline $1442-2 b$ & $6 / 14^{b}$ & $9 / 9^{b}$ & + & $8 / 14$ & $9 / 10$ & + & $2 / 3$ & $2 / 2$ & + & $3 / 3$ & $3 / 3$ & + \\
\hline $1467-a$ & $4 / 13^{b}$ & $9 / 9^{b}$ & + & $7 / 13$ & $5 / 9$ & + & $1 / 3$ & $2 / 3$ & + & $3 / 3$ & $2 / 3$ & + \\
\hline 1467-a & $7 / 14^{\mathrm{b}}$ & $9 / 9^{b}$ & + & $6 / 14$ & $7 / 10$ & + & $3 / 3$ & $3 / 3$ & + & $3 / 3$ & $2 / 3$ & + \\
\hline PBS & $0 / 7$ & $0 / 3$ & - & $0 / 8$ & $0 / 4$ & - & $0 / 2$ & NT & - & $0 / 2$ & NT & - \\
\hline PBS & $0 / 9$ & $0 / 3$ & - & $0 / 7$ & $0 / 4$ & - & $0 / 2$ & NT & - & $0 / 2$ & $\mathrm{NT}$ & - \\
\hline
\end{tabular}

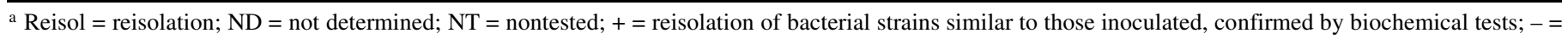
no reisolation of Brenneria-like colonies.

${ }^{\mathrm{b}} P<0.05$ for comparison between 3- and 5-year-old holm oaks analyzed for internal symptom occurrence 3 or 28 months after inoculation. 
The fatty acid composition of the isolates studied indicated that they were members of the family Enterobacteriaceae $(7,29)$ but did not differentiate the Californian strain from the Spanish isolates. The difficulties in using the MIS system for accurate identification of $B$. quercina could be due to the library utilized (7). However, the FAME profiles of the Spanish isolates and the Californian strain were very similar to those previously reported for the type strain of B. quercina NCPPB $1852^{\mathrm{T}}$ (29), reinforcing the identification of Spanish oak isolates as belonging to this species.

The serological analysis of Spanish isolates of B. quercina revealed that most of them reacted against the three antisera, showing that they have many antigens in common, regardless of their geographical origin and host. However, some antigenic heterogeneity was observed among them in IF-I and ELISA-I. In this sense, Spanish isolates coming from trunk bark cankers (1251, 1442 , and 1467) were more closely related than those coming from sap oozing from acorns and buds (1618 and 1625). Surprisingly, the Californian strain CFBP 1266 from drippy nut showed a higher degree of relatedness with isolates from bark canker than with the Spanish isolates from acorn and leaf bud exudations. Similar results were obtained with antiserum 1467a, which confirmed some antigenic heterogeneity between Spanish isolates from different origins.

Spanish isolates of $B$. quercina were able to reproduce the symptoms caused by this bacterium under natural conditions in excised acorns, although oozing was not as abundant as in natural acorns attached to trees, agreeing with previous studies (12). However, in contrast to the results of Hildebrand and Schroth (12), the expression of symptoms was observed only when excised acorns were inoculated by immersion, not by a needle, suggesting that the bacterium might prefer entry through some natural openings. Maybe the anatomic and physiological differences between the nuts of the Californian and the Spanish oak species could explain the different results obtained.

Trunk inoculations of oak trees growing in pots or in the field further demonstrated that all tested isolates, as well as the reference strain CFBP 1266, were pathogenic for holm oak and $Q$. pyrenaica. Differences in the length of internal lesions were found in young trees (analyzed after 3 or 28 months), but not for mature trees. This observation suggests that the lesions produced by this bacterium in young plants can progress for months or years after inoculation; whereas, in older oaks, they occur within the first few months after inoculation, at least under the conditions of the two experiments performed. Significant differences in symptom development on young holm oak trees suggested that the pathogen spreads slowly in them compared with older trees. In fact, the bark cankers detected in the surveyed areas always were observed in mature trees. We observed external cankers with exudates in just a few potted trees and they were similar to those caused by $B$. quercina under natural conditions. However, small necrotic bark areas around the inoculation points in the trees inoculated with the drippy nut pathogen were of similar size to those reported in pathogenicity assays in walnut trees injected with $B$. nigrifluens (33). Although artificial inoculation of B. quercina did not always lead to the formation of cankers, internal necrosis, discoloration and degradation of host tissues, or reisolation from tissues distant from the inoculation site, demonstrated that this bacterium is able to colonize oak tissues, cause lesions, and survive for long periods. In addition, difficulties in reproducing external cankers of a certain size frequently have been reported by researchers inoculating woody plants with plant-pathogenic bacteria, including $B$. nigrifluens and $B$. rubrifaciens $(9,15,17,33)$. This difficulty could be due to differences between natural infection conditions and artificial inoculations, the inoculation period, or the physiological state of the tissues at the inoculation time and the following weeks. Finally, whether the external lesions observed under natural conditions are produced by or just used by Brenneria spp. to enter into the plant remains to be determined.
This article reports the first European isolation of $B$. quercina and its association with bark canker of oak trees. The Spanish isolates of $B$. quercina were found in exudative bark cankers on $Q$. ilex and $Q$. pyrenaica and dark-brown sap exudate on bark is one of the symptoms observed in trees with oak decline; therefore, we believe this bacterium may be one of the biotic factors involved in the syndrome affecting $Q$. ilex and $Q$. pyrenaica in Spanish forests. Its role in the symptomatology on oaks observed in other countries should be determined.

\section{ACKNOWLEDGMENTS}

This work was supported by the grant 1FD97-0911-C03-02 of the FEDER program from the E.U. and by an agreement with the Ministerio de Medio Ambiente, Madrid, Spain. We thank M. T. Gorris of the Instituto Valenciano de Investigaciones Agrarias for helping in the serological analysis; A. Marzo, J. Martínez, and P. Guirao of the Banco de Semillas Forestales, Consellería de Medio Ambiente, Valencia, Spain for providing young oak trees; J. L. Díez for helping with statistical analysis; and D. Barraclough and F. Donnellan for English language revision. E. G. Biosca and R. González contributed equally to this study.

\section{LITERATURE CITED}

1. Appel, D. N. 1995. The oak wilt enigma. Annu. Rev. Phytopathol. 33:103-118.

2. Ayers, S. H., Rupp, P., and Johnson, W. T. 1919. A study of the alkaliforming bacteria in milk. U.S. Dep. Agric. Bull. 782:39.

3. Barnard, E. L., Ash, E. C., Hopkins, D. L., and McGovern, R. J. 1998. Distribution of Xylella fastidiosa in oaks in Florida and its association with growth decline in Quercus laevis. Plant Dis. 82:569-572.

4. Brasier, C. M. 1996. Phytophthora cinnamomi and oak decline in southern Europe: Environmental constraints including climate change. Ann. Sci. For. 53:347-358.

5. Cobos, J. M., Montoya, R., and Tuset, J. J. 1993. New damages of the Quercus woodlands in Spain. Preliminary evaluation of the possible implication of Phytophthora cinnamomi. Pages 163-169 in: Proc. Int. Congr. Recent Adv. Studies Oak Decline. N. Luisi, P. Lerario, and A. Vannini, eds. Univ. degli Studi, Bari, Italy.

6. Delatour, C. 1983. Les dépérissements des chênes en Europe. Biol. Fôret. XXXV:265-282.

7. Dickstein, E. R., Jones, J. B., and Stead, D. E. 2001. Automated techniques. Pages 343-345 in: Laboratory Guide for Identification of Plant Pathogenic Bacteria. N. W. Schaad, J. B. Jones, and W. Chun, eds. The American Phytopathological Society, St. Paul, MN.

8. Fernández Cancio, A. 2000. Impacto del cambio climático en las secas del Parque Natural de los Alcornocales, análisis del último milenio. Informe INIA (MAPA), Madrid.

9. González, R., López-López, M. J., Biosca, E. G., López, F., Santiago, R., and López, M. M. 2002. First report of bacterial deep bark canker of walnut caused by Brenneria (Erwinia) rubrifaciens in Europe. Plant Dis. $86: 696$.

10. Hampton, R., Ball, E., and De Boer, S. 1990. Serological Methods for Detection and Identification of Viral and Bacterial Plant Pathogens. The American Phytopathological Society, St. Paul, MN.

11. Hauben, L., Moore, E., Vauterin, L., Steenackers, M., Mergaert, J., Verdonck, L., and Swings, J. 1998. Phylogenetic position of phytopathogens within the Enterobacteriaceae. Syst. Appl. Microbiol. 21:384-397.

12. Hildebrand, D. C., and Schroth, M. N. 1967. A new species of Erwinia causing the drippy nut disease of live oaks. Phytopathology 57:250-253.

13. Holt, J. G., Krieg, N. R., Sneath, P. H. A., Staley, J. T., and Williams, S. T. 1994. Bergey's Manual of Determinative Bacteriology. 9th ed. The Williams \& Wilkins Co., Baltimore, MD.

14. King, E. O., Ward, M. K., and Raney, D. E. 1954. Two simple media for the demonstration of pyocyanin and fluorescein. J. Lab. Clin. Med. 44:301-307.

15. Klement, Z. 1990. Inoculation of plant tissues. Pages 104-105 in: Methods in Phytobacteriology. Z. Klement, K. Rudolph, and D.C. Sands, eds. Akadémiai Kiado, Budapest, Hungary.

16. Leininger, T. D. 1996. Oak physiology under temperature and drought stress as it relates to the oak decline syndrome. Annu. Abstr. Phytopathol. 86:387.

17. López, M. M., Martí, R., Morente, C., Orellana, N., Ninot, T., and Aleta, N. 1994. Bacterias fitopatógenas identificadas en nogal en España. Invest. Agrar. 2:307-314.

18. Luisi, N., Sicoli, G., and Lerario, P. 1996. Observations on Armillaria occurrence in declining oak woods of southern Italy. Ann. Sci. For. 
53:389-394.

19. Marcais, B., Dupuis, F., and Desprez-Loustau, M. L. 1996. Susceptibility of the Quercus rubra root system to Phytophthora cinnamomi: Comparison with chestnut and other oak species. Eur. J. For. Pathol. 26:133-143.

20. Raabe, R. D. 1990. Diseases of native oaks in California. Fremontia 18:64-67.

21. Ragazzi, A., Fedi, I. D., and Mesturino, L. 1989. The oak decline: A new problem in Italy. Eur. J. For. Pathol. 19:105-110.

22. Rizzo, D. M., Garbelotto, M., Davidson, J. M., Slaughter, G. W., and Koike, S. T. 2001. Phytophthora ramorum as the cause of extensive mortality of Quercus spp. and Lithocarpus densiflorus in California. Plant Dis. 86:205-214.

23. Rupérez, A., and Muñoz, M. C. 1980. Grave enfermedad de las encinas. Bol. San. Veg. Plagas. 107.

24. Sasser, M. 1990. Identification of bacteria through fatty acid analysis. Pages 199-204 in: Methods in Phytobacteriology. Z. Klement, K. Rudolph, and D.C. Sands, eds. Akadémiai Kiado, Budapest, Hungary.

25. Schroth, M. N., and Hildebrand, D. C. 1988. Erwinia. In: Laboratory Guide for Identification of Plant Pathogenic Bacteria. N. W. Schaad, ed. The American Phytopathological Society, St. Paul, MN.

26. Schütt, P., and Cowling, E. B. 1985. Waldsterben, a general decline of forest in central Europe. Symptoms development, and possible causes. Plant Dis. 69:547-558.

27. Scortichini, M., Stead, D. E., and Rossi, M. P. 1993. Oak decline: aerobic bacteria associated with declining Quercus cerris in Central
Italy. Eur. J. For. Pathol. 23:120-127.

28. Soria, S., López, M. M., and López, M. J. 1997. Presencia, sintomatología y daños de Erwinia quercina en España y su posible relación con la seca de la encina. Ecología 11:295-301.

29. Surico, G., Mugnai, L., Pastorelli, R., Giovannetti, L., and Stead, D. E. 1996. Erwinia alni, a new species causing bark cankers of alder (Alnus miller) species. Int. J. Syst. Bacteriol. 46:720-726.

30. Tusset, J. J., Hinarejos, C., Mira, J. L., and Cobos, J. M. 1996. Implicación de Phytophthora cinnamomi Rands en la enfermedad de la "seca" de encinas y alcornoques. Bol. San. Veg. Plagas. 22:491-499.

31. Vannini, A., Valentini, R., and Luisi, N. 1996. Impact of drought and Hypoxylon mediterraneum on oak decline in the Mediterranean region. Ann. Sci. For. 53:753-760.

32. Wargo, P. M. 1993. Multiple factors in oak decline in the United States. Pages 1-9 in: Proc. Int. Congr. Recent Adv. Studies Oak Decline. N. Luisi, P. Lerario, and A. Vannini, eds. Univ. degli Studi, Bari, Italy.

33. Wilson, E. E., Starr, M. P., and Berger, J. A. 1957. Bark canker, a bacterial disease of Persian walnut tree. Phytopathology 47:669-673.

34. Wilson, E. E., Zeitoun, F. M., and Fredrickson, D. L. 1966. Bark phloem canker, a new disease of Persian walnut trees. Phytopathology 57:618621.

35. Wright, A. E., Shafer, M., Midland, S., Munnecke, D. E., and Sims, J. J. 1989. Lateral root inducing compounds from the bacterium Erwinia quercina: Isolation, structure and synthesis. Tetrahedron Lett. 30:56995702. 